\title{
A Chromo- and Fluoroionophoric Thiaoxaaza-Macrocycle Functionalized with Nitrobenzofurazan Exhibiting Mercury(II) Selectivity
}

\author{
Ji-Eun Lee, ${ }^{\dagger, *}$ Shim Sung Lee, ${ }^{\ddagger * *}$ and Kyu Seong Choi ${ }^{\S, *}$ \\ ${ }^{\dagger}$ Central Instrument Facility, Gyeongsang National University, Jinju 660-701, Korea \\ ${ }^{\star}$ Department of Chemistry (WCU) and RINS, Gyeongsang National University, Jinju 660-701, Korea \\ ${ }^{*}$ E-mail: sslee@gsnu.ac.kr \\ ${ }^{\S}$ Department of Science Education, Kyungnam University, Masan 631-701, Korea. ${ }^{*}$ E-mail: kschoi@kyungnam.ac.kr \\ Received September 17, 2010, Accepted October 18, 2010
}

\begin{abstract}
A chromo/fluorogenic $\mathrm{NO}_{2} \mathrm{~S}_{2}$-macrocycle $\mathbf{L}$ functionalized with nitrobenzofurazan unit as a dual-signaling probe was synthesized and structurally characterized by single crystal X-ray analysis. In a cation-induced color change experiment, Lexhibited excellent $\mathrm{Hg}^{2+}$ ion selectivity by showing the color change from orange-red to yellow. However, this hypochromic shift by $\mathrm{Hg}^{2+}$ was observed for the weaker coordinating anion system such as $\mathrm{NO}_{3}^{-}$and $\mathrm{ClO}_{4}^{-}$ions. The observed anion effect is due to the strong coordination of anions inhibits the bond formation between $\mathrm{Hg}^{2+}$ and the macrocyclic tert-N atom, which is sensitive to induce the color change. In the fluorometric experiment, $\mathbf{L}$ showed chelate-enhanced fluorescence change effect only with $\mathrm{Hg}^{2+}$ ion, together with a change from yellow to green emission. The sensing ability for $\mathrm{Hg}^{2+}$ with the proposed chemosensor $\mathbf{L}$ is due to the stable complexation with 1:1 stoichiometry (metal-toligand).
\end{abstract}

Key Words: $\mathrm{NO}_{2} \mathrm{~S}_{2}$-Macrocycle, Dual-signaling probe, Chromoionophore, Fluoroionophore, $\mathrm{Hg}^{2+}$-selectivity

\section{Introduction}

Due to the extreme toxicity of mercury in clinical and environmental areas, many efforts have been devoted to design and prepare various types of mercury(II) sensors. ${ }^{1-3} \mathrm{~A}$ wide range of chemosensors for $\mathrm{Hg}^{2+}$ have been progressively improved using redox, chromogenic, or fluorogenic changes. ${ }^{4-11}$ Previously, we also reported the pyridine-based $\mathrm{N}_{2} \mathrm{~S}_{2}$ macrocycles functionalized with $p$-nitrobenzene and phenyltricynovinyl moieties, which display attractive color changes by selective $\mathrm{Hg}^{2+}$ sensing. ${ }^{12}$ Despite the development of individual chromogenic and fluorogenic receptor molecules, there are few examples of receptors capable of displaying two or more signals upon guest (mercury) binding. ${ }^{13-15}$ Some organic dye molecules exhibit not only color but also fluorescence. The 7-nitrobenzo-2oxa-1,3-diazolyl (NBD) unit is a chromo/fluorophore and seemed ideal probe for incorporation in new type of dual-signaling receptors. ${ }^{16-19}$ As an extension of our previously results for the $\mathrm{Hg}^{2+}$ sensing host system with mono-channel (color) probe, ${ }^{12}$ we have worked on the functional macrocycle in terms of the construction of dual-channel (color/fluorescence) probe sensing system. We herein report the synthesis of NBD-attached $\mathrm{NO}_{2} \mathrm{~S}_{2}$ macrocycle $\mathbf{L}$ (Scheme 1) and its photophysical behaviors as a mercury(II) sensor.

\section{Results and Discussion}

As a key precursor, $\mathrm{NO}_{2} \mathrm{~S}_{2}$ macrocycle $\mathbf{4}$ was synthesized by mercaptan-dihalide coupling reaction of $N$-Boc-dithiol (1) with dibenzo-dichloride (2) in high dilution condition and then Bocdeprotection as reported previously (Scheme 1). ${ }^{22}$ Reaction of the macrocycle 4 with 1.1 equiv of NBD chloride 5 in toluene afforded the target compound 9-(7-nitrobenzo[c][1,2,5]oxadiazol-4-yl)-7,8,9,10,11,13,19,20-octahydro-5H-dibenzo[e,p]

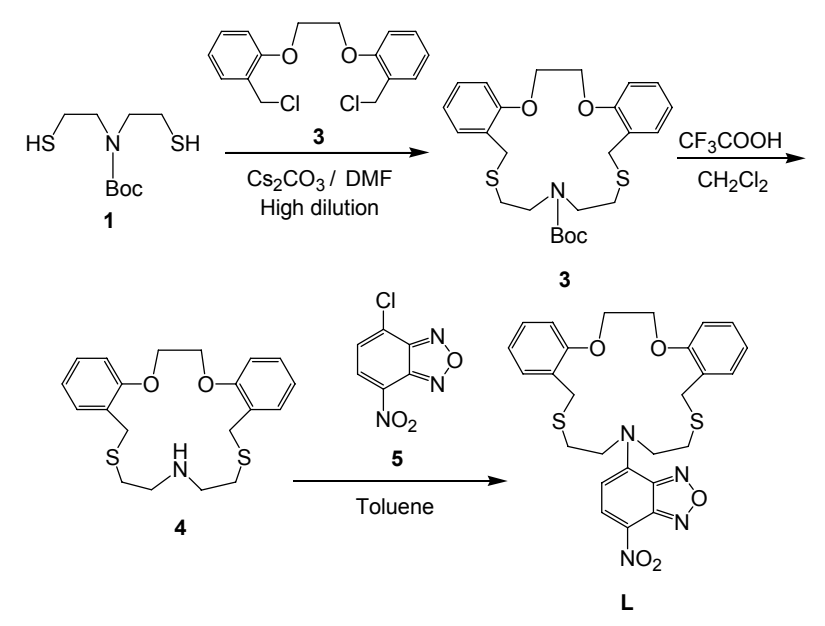

Scheme 1. Synthesis of $\mathbf{L}$

$[1,4,8,14,11]$ dioxadithiaazacycloheptadecine (L) as an orangecolored solid.

In acetonitrile, $\mathbf{L}$ displays very sensitive orange color $\left(\lambda_{\max }=\right.$ $486 \mathrm{~nm}, \lambda_{\max }=24,000 \mathrm{M} \mathrm{cm}^{-1}$ ) which can be assigned to chargetransfer absorptions (Fig. 1a). ${ }^{15-18} \mathbf{L}$ also showed an intense yellow fluorescence around $536 \mathrm{~nm}$, which is typical of the NBD moiety $\left(\lambda_{\text {ex }}=480 \mathrm{~nm}\right)$ (Fig. 1b). ${ }^{16-19}$

Colorless crystals of $\mathbf{L}$ suitable for X-ray crystallography were grown by vapor diffusion of diethyl ether into a dichloromethane solution of this ligand at room temperature. The molecular structure of $\mathbf{L}$ is shown in Fig. 2 The macrocyclic unit is folded over the NBD subunit. The intercentroid distance of the NBD and the closest benzo moiety is $3.466 \AA$, reflecting the presence of an offset-face-to-face $\pi-\pi$ interaction. Two oxygen atoms are orientated endodentate and two sulfur donors are 


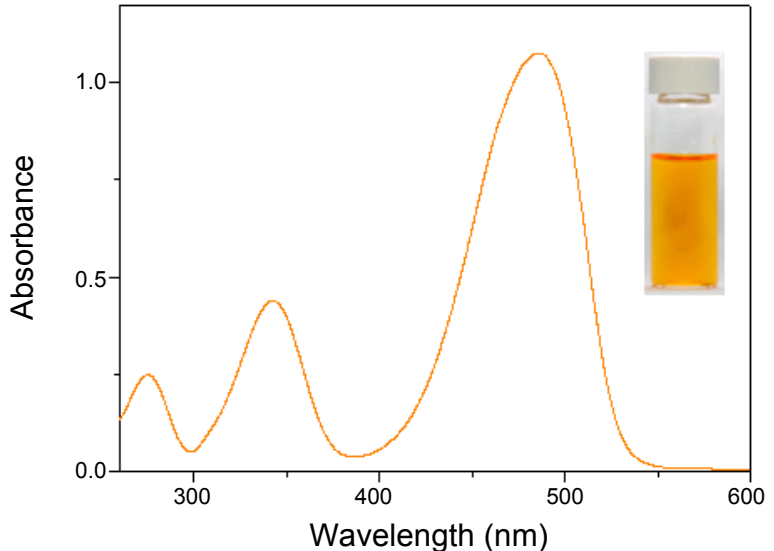

(a)

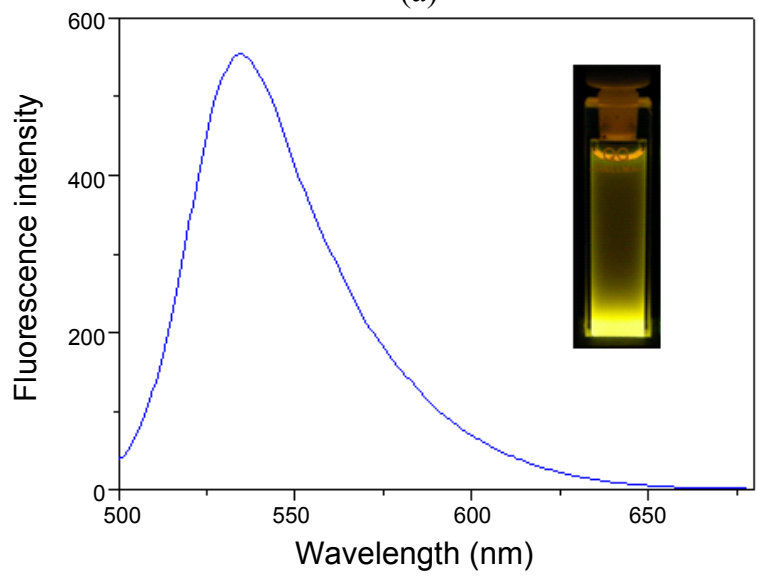

(b)

Figure 1. (a) UV-vis and (b) fluorescence spectra of $\mathbf{L}$ in acetonitrile.

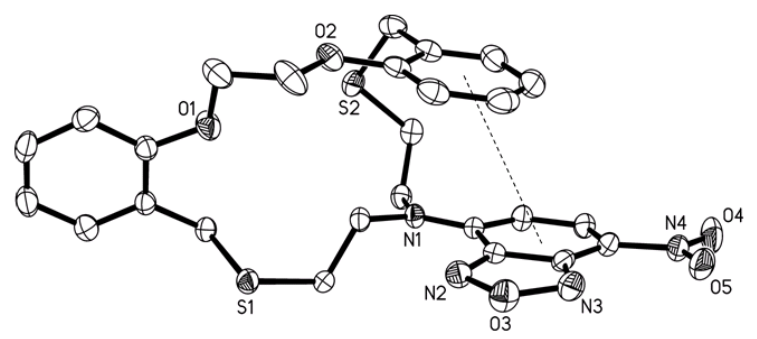

Figure 2. Molecular structure of $\mathbf{L} \cdot 0.5 \mathrm{CH}_{2} \mathrm{Cl}_{2}$ showing an offset-faceto-face $\pi-\pi$ interaction (dashed line, centroid-to-centroid distance: $3.466 \AA$ ). Hydrogen atoms and solvent molecule are omitted.

exodentate with respect to the macrocyclic cavity. The S1 $\cdots \mathrm{S} 2$ distance is large at 5.490(2) $\AA$, presumably due to the presence of a repulsive interaction between these donors. The ligand torsion angles between donor atoms are indicative of gauche arrangements [O1-C-C-O2 71.8(4) ${ }^{\circ}$ and S2-C-C-N1 -76.2(3) ${ }^{\circ}$ ] except that for N1-C-C-S1 $\left[-171.9(2)^{\circ}\right]$.

We next investigated the metal-induced color changes of the ligand in acetonitrile by adding the group $\mathrm{I}$ and $\mathrm{II}\left(\mathrm{Li}^{+}, \mathrm{Na}^{+}, \mathrm{K}^{+}\right.$, and $\left.\mathrm{Ba}^{2+}\right)$, transition and heavy $\left(\mathrm{Ni}^{2+}, \mathrm{Cu}^{2+}, \mathrm{Zn}^{2+}, \mathrm{Al}^{3+}, \mathrm{Ag}^{+}\right.$, $\mathrm{Hg}^{2+}, \mathrm{Cd}^{2+}$, and $\mathrm{Pb}^{2+}$ ) metal ions. Fig. 3a shows the spectral changes of $\mathbf{L}$ after adding 5.0 equiv of the metal perchlorates together with the corresponding color changes before and after adding $\mathrm{Hg}^{2+}$. Notably, the large metal-induced hypochromic shift for $\mathrm{Hg}^{2+}(\Delta \lambda=86 \mathrm{~nm})$ resulted color change from red-

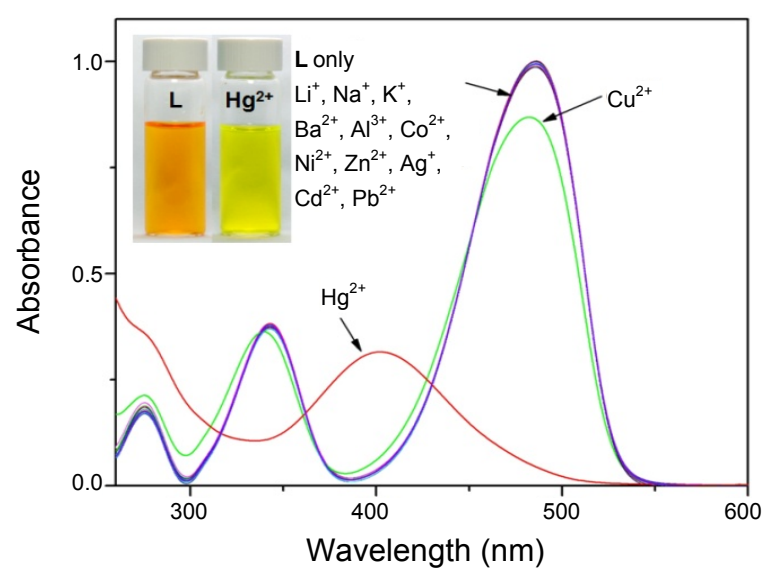

(a)

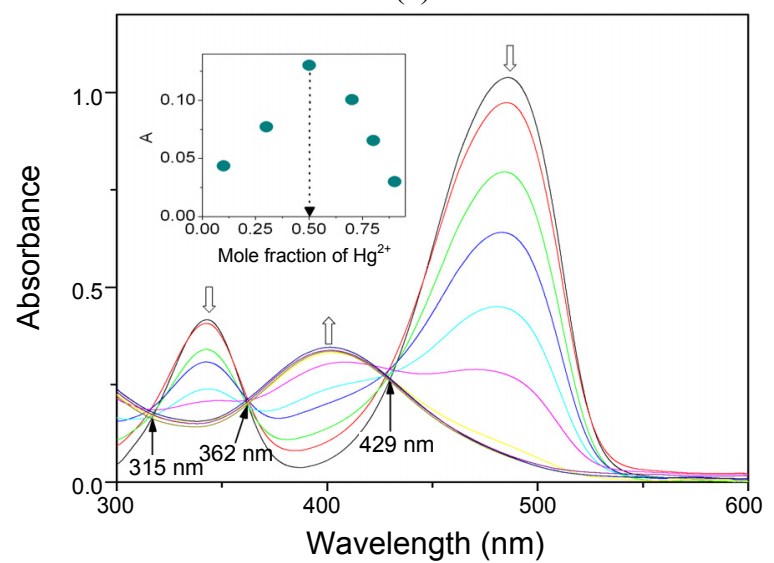

(b)

Figure 3. (a) UV-vis spectra of $\mathbf{L}$ on addition of metal perchlorates (ligand concentration: $0.05 \mathrm{mM}$ in $\mathrm{CH}_{3} \mathrm{CN}$, added metal ion: 5.0 equiv) and (b) UV-vis titration of $\mathbf{L}(0.050 \mathrm{mM})$ with $\mathrm{Hg}\left(\mathrm{ClO}_{4}\right)_{2}$ ( 0 - 5.0 equiv) in acetonitrile; (inset) Job's plot.

orange to yellow. Whereas, no significant color changes were observed upon addition of selected other metal ions. The color change is attributed to the metal coordination with the bridgehead nitrogen donor (N1 in Fig. 3a) in $\mathbf{L}$.

Obvious complex formation of $\mathbf{L}$ was clearly observed when it was titrated with $\mathrm{Hg}^{2+}$ in acetonitrile (Fig. 3b). The stepwise addition of $\mathrm{Hg}^{2+}$ causes the ligand absorption (486 nm) to gradually decrease, whereas the complex absorption $(400 \mathrm{~nm})$ increases to give isosbestic points at 315,362 and $429 \mathrm{~nm}$. The spectral features in Fig. $3 \mathrm{~b}$ are consistent with a 1:1 binding ratio between ligand and $\mathrm{Hg}^{2+}$. Further support for $1: 1$ binding was also demonstrated by means of a Job's plot experiment. The apparent weaker affinity of $\mathbf{L}$ towards metals may be explained by the effect of the strong electron-withdrawing NBD group, which may inhibit the coordination of the nitrogen donor to $\mathrm{Hg}^{2+}$. From these results, it is noted that the unique behavior of the proposed ligand system can thus be attributed to its selective complexation affinity for $\mathrm{Hg}^{2+}$.

We also found that the color change for $\mathbf{L}$ with $\mathrm{Hg}^{2+}$ can be affected by the anion employed. For instance, the addition of $\mathrm{NO}_{3}{ }^{-}$or $\mathrm{ClO}_{4}{ }^{-}$resulted in hypochromic shifts in the spectrum of the mercury complex to $440 \mathrm{~nm}\left(\mathrm{NO}_{3}{ }^{-}\right)$and $400 \mathrm{~nm}\left(\mathrm{ClO}_{4}{ }^{-}\right)$ (pale-yellow), respectively (Fig. 4). However, no color changes were observed upon addition of $\mathrm{Cl}^{-}, \mathrm{Br}^{-}, \mathrm{I}^{-}, \mathrm{AcO}^{-}, \mathrm{SCN}^{-}$, or $\mathrm{SO}_{4}{ }^{2-}$. 


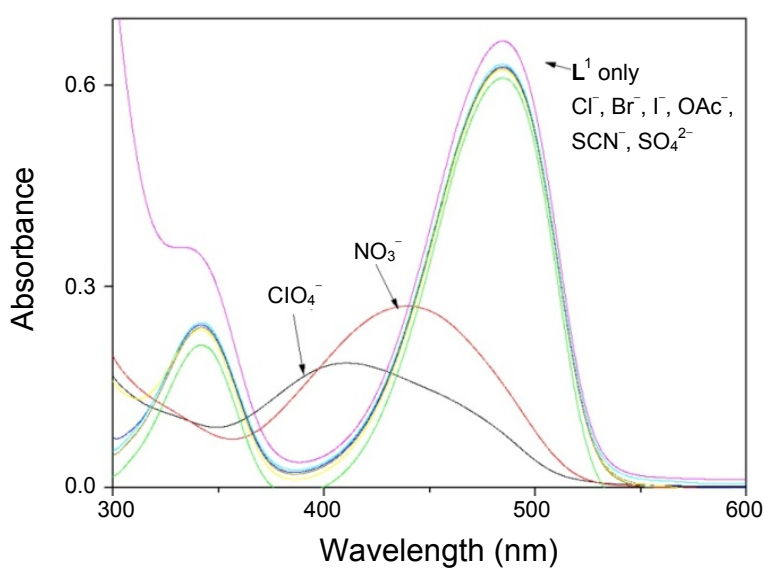

Figure 4. Anion-dependent UV-vis spectral changes of $\mathbf{L}$ for different $\mathrm{Hg}(\mathrm{II})$ salts in acetonitrile.

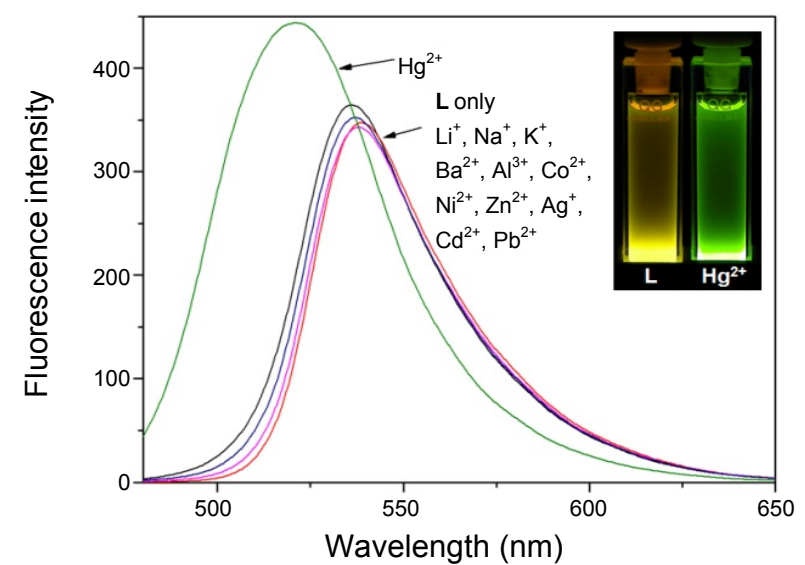

(a)

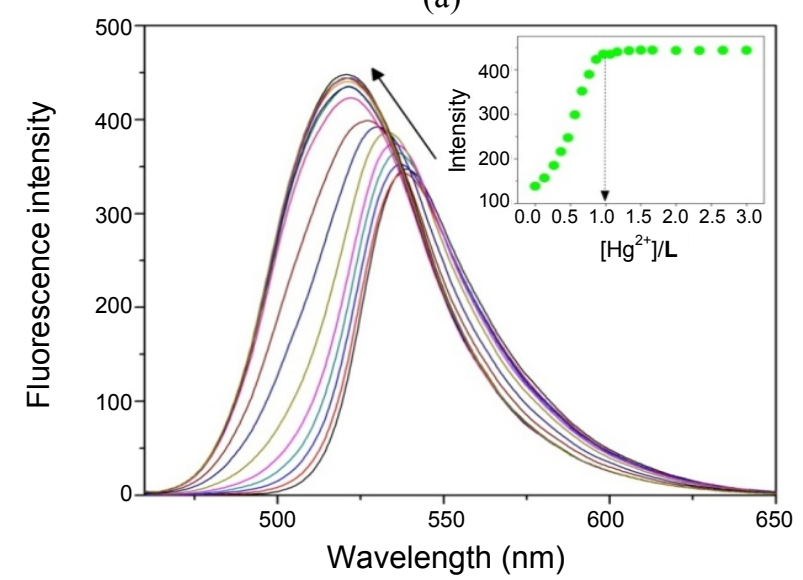

(b)

Figure 5. (a) Fluorescence spectra of $\mathbf{L}$ on addition of metal perchlorates (ligand concentration: $0.05 \mathrm{mM}$ in $\mathrm{CH}_{3} \mathrm{CN}$, added metal ion: 5.0 equiv) and (b) Fluorescence titration spectra for $\mathbf{L}(0.050 \mathrm{mM})$ with $\mathrm{Hg}\left(\mathrm{ClO}_{4}\right)_{2}$ (0-5.0 equiv) in acetonitrile; (inset: fluorescence intensity at $520 \mathrm{~nm} v s$ the number of equivalents of $\mathrm{Hg}^{2+}$ added to $\mathbf{L}$ ).

This is attributed to the stronger coordination ability of these latter anions to $\mathrm{Hg}^{2+}$ ion, because the strong coordination of anions inhibits the bond formation between $\mathrm{Hg}^{2+}$ and the macrocyclic tert-N atom, which is sensitive to induce the color change. The similar behaviors were reported in terms of the strong coordination of these latter anions acting to prevent $\mathrm{Hg}$ -
$\mathrm{N}_{\text {bridgehead }}$ bond formation, resulting in no color change. ${ }^{23}$ In this case, the $\mathrm{Hg}^{2+}$ ion is expected to bind to two sulfur doners. ${ }^{23}$

The binding properties of $\mathbf{L}$ were also examined with respect to its fluorescence behavior. L shows a yellow fluorescence at $536 \mathrm{~nm}$ in acetonitrile. The fluoroionophoric behavior of $\mathbf{L}$ was investigated in acetonitrile on addition of metal ions. Fig. 5a shows the spectral changes for $\mathbf{L}$ after adding 5.0 equiv of the metal perchlorates shown together with the corresponding fluorescence emission changes. Interestingly, a cation-induced blue shift occurred for $\mathrm{Hg}^{2+}(\Delta \lambda=16 \mathrm{~nm})$, resulting in a change from yellow to green fluorescence; whereas, no significant color changes were observed upon addition of the other metal ions employed.

The fluorescence titration of $\mathbf{L}$ with $\mathrm{Hg}\left(\mathrm{ClO}_{4}\right)_{2}$ were also carried out. As shown in Fig. 5b, upon adding $\mathrm{Hg}^{2+}$ ion, the fluorescence intensity of $\mathbf{L}$ increases and is accompanied by a blue shift in the emission spectrum. The emission spectrum of free $\mathbf{L}$ displays a band with a maximum at $536 \mathrm{~nm}$. When $\mathrm{Hg}^{2+}$ was added to the solution of $\mathbf{L}$, an intensity increase at $520 \mathrm{~nm}$ was observed. Further support of the 1:1 binding ratio was demonstrated by means of a fluorescence titration experiment (see inset of Fig. 5b).

\section{Conclusion}

In summary, the chromo- and fluorogenic NBD-attached $\mathrm{NO}_{2} \mathrm{~S}_{2}$-macrocycle $\mathbf{L}$ was synthesized and its structure was confirmed by NMR and X-ray crystallography. A cation-induced hypochromic shift for $\mathrm{Hg}^{2+}$ was observed resulting in a color change from orange to pale-yellow. Whereas, no significant color changes were observed upon addition of the selected other metal ions. In the fluorescence study for $\mathbf{L}$, only $\mathrm{Hg}^{2+}$ induced fluorescence emission changes from yellow to green. These were monitored by both colorimetric and fluorescence techniques that showed fast 1:1 stoichiometric responses to the amount of $\mathrm{Hg}^{2+}$ present in solution.

\section{Experimental Section}

General methods. All commercial reagents including solvents were of analytical reagent grade. NMR spectra were recorded on a Bruker DRX-300 spectrometer (300 MHz). Infrared spectra were measured with a Mattson Genesis Series FT-IR spectrophotometer. The mass spectra were obtained on a JEOL JMS-700 spectrometer at the Central Instrument Facility of Gyeongsang National University. The melting points were determined on a Electrothermal IA-9200 laboratory device and were not corrected.

Synthesis of L. A solution of 4-chloro-7-nitro-benzofurazan in toluene (11 $\mathrm{mmol}$ in $40 \mathrm{~mL}$ ) was added dropwise to a boiling solution of precursor macrocycle 4 in toluene (10 mmol in $150 \mathrm{~mL}$ ). The reaction mixture was then maintained at reflux for $3 \mathrm{~h}$ with rapid stirring, allowed to cool to room temperature, then filtered. The filtrate was evaporated and the residue was partitioned between water and dichloromethane. The aqueous phase was separated and extracted with two further portions of dichloromethane. The combined organic phases were dried with anhydrous sodium sulfate and then evaporated to dryness. Column chromatography on silica gel (30\% ethyl acetate/ $n$-hex- 
Table 1. Crystal data and structural refinement

\begin{tabular}{ll}
\hline & \multicolumn{1}{c}{$\mathbf{L} \cdot 0.5 \mathrm{CH}_{2} \mathrm{Cl}_{2}$} \\
\hline Formula & $\mathrm{C}_{26.5} \mathrm{H}_{26} \mathrm{ClN}_{4} \mathrm{O}_{5} \mathrm{~S}_{2}$ \\
$M$ & 580.08 \\
$T / K$ & $173(2)$ \\
Crystal system & Monoclinic \\
Space group & $C 2 / c$ \\
$a / \AA$ & $16.998(2)$ \\
$b / \AA$ & $8.861(1)$ \\
$c / \AA$ & $36.424(5)$ \\
$\beta /{ }^{\circ}$ & $99.648(2)$ \\
$V / \AA^{3}$ & $5409(1)$ \\
$Z$ & 8 \\
$\mu($ MoK $\alpha) / m^{-1}$ & 0.341 \\
Reflections collected & 12701 \\
Independent reflections & 5176 \\
Goodness-of-fit on $F^{2}$ & 1.055 \\
Final $R_{1}, w R_{2}[I>2 \sigma(I)]$ & $0.0595,0.1430$ \\
All data & $0.0935,0.1630$ \\
\hline
\end{tabular}

Table 2. Selected bond lengths $(\AA)$, bond angles $\left(^{\circ}\right)$ and torsion angles $\left({ }^{\circ}\right)$ for $\mathbf{L} \cdot 0.5 \mathrm{CH}_{2} \mathrm{Cl}_{2}$

\begin{tabular}{llll}
\hline $\mathrm{S}(1)-\mathrm{C}(9)$ & $1.801(3)$ & $\mathrm{Hg}(1)-\mathrm{Cl}(2)$ & $2.364(3)$ \\
$\mathrm{S}(1)-\mathrm{C}(8)$ & $1.820(3)$ & $\mathrm{Hg}(1)-\mathrm{S}(2)$ & $2.657(3)$ \\
$\mathrm{S}(2)-\mathrm{C}(12)$ & $1.814(4)$ & $\mathrm{Hg}(1) \cdots \mathrm{O}(1)$ & $5.418(9)$ \\
$\mathrm{S}(2)-\mathrm{C}(13)$ & $1.818(4)$ & & \\
\hline $\mathrm{C}(9)-\mathrm{S}(1)-\mathrm{C}(8)$ & $99.56(15)$ & $\mathrm{C}(21)-\mathrm{N}(1)-\mathrm{C}(11)$ & $120.1(3)$ \\
$\mathrm{C}(12)-\mathrm{S}(2)-\mathrm{C}(13)$ & $103.53(18)$ & $\mathrm{C}(21)-\mathrm{N}(1)-\mathrm{C}(10)$ & $124.2(3)$ \\
$\mathrm{C}(2)-\mathrm{O}(1)-\mathrm{C}(1)$ & $119.4(3)$ & $\mathrm{C}(11)-\mathrm{N}(1)-\mathrm{C}(10)$ & $115.7(2)$ \\
$\mathrm{C}(19)-\mathrm{O}(2)-\mathrm{C}(20)$ & $117.9(3)$ & & \\
\hline $\mathrm{O}(1)-\mathrm{C}(1)-\mathrm{C}(20)-\mathrm{O}(3)$ & $78.8(4)$ & $\mathrm{S}(1)-\mathrm{C}(9)-\mathrm{C}(10)-\mathrm{N}(1)$ & $-76.2(3)$ \\
$\mathrm{S}(2)-\mathrm{C}(12)-\mathrm{C}(11)-\mathrm{N}(1)$ & $-171.9(2)$ & & \\
\hline
\end{tabular}

ane) gave $\mathbf{L}$ as an orange-colored solid. Yield: $52 \%$. mp 120 $122{ }^{\circ} \mathrm{C} .{ }^{1} \mathrm{H}$ NMR $\left(300 \mathrm{MHz}, \mathrm{CDCl}_{3}\right) \delta 2.78\left(\mathrm{t}, 4 \mathrm{H}, \mathrm{SCH}_{2} \mathrm{CH}_{2}\right)$, $\delta 3.88\left(\mathrm{~s}, 4 \mathrm{H}, \mathrm{ArCH}_{2}\right), \delta 4.16\left(\mathrm{~m}, 4 \mathrm{H}, \mathrm{NCH}_{2} \mathrm{CH}_{2}\right), \delta 4.41(\mathrm{~s}$, $\left.4 \mathrm{H}, \mathrm{OCH}_{2}\right), \delta 5.87(\mathrm{~d}, 1 \mathrm{H}, \mathrm{NBD}), 6.09-7.37(\mathrm{~m}, 8 \mathrm{H}, \mathrm{Ar}), \delta$ $8.30(\mathrm{~d}, 1 \mathrm{H}, \mathrm{NBD}) .{ }^{13} \mathrm{CNMR}\left(75 \mathrm{MHz}, \mathrm{CDCl}_{3}\right) \delta 156.3,144.1$, 135.1, 131.1, 128.7, 121.7, 111.9, 101.3, 67.5, 47.2, 31.4, 29.4. IR $\left(\mathrm{KBr}, \mathrm{cm}^{-1}\right): 3383,2923,1678,1494,1451,1241,763$. HRMS $(\mathrm{m} / \mathrm{z})$ calcd. For $\mathrm{C}_{26} \mathrm{H}_{26} \mathrm{~N}_{4} \mathrm{O}_{5} \mathrm{~S}_{2}: 538.1345$; found: 538.1344.

Crystallography. A crystal suitable for X-ray diffraction was mounted on a Bruker SMART diffractometer equipped with a graphite monochromated Mo K $\alpha(\lambda=0.71073 \AA)$ radiation source and a CCD detector and 45 frames of two-dimensional diffraction images were collected and processed to deduce the cell parameters and orientation matrix. A total of 1271 frames of two-dimensional diffraction images were collected, each of which was measured for $30 \mathrm{~s}$. The frame data were processed to give structure factors by the program SAINT..$^{20}$ The intensity data were corrected for Lorentz and polarization effects. The structures were solved by a combination of the direct method and the difference Fourier methods provided by the program package SHELXTL, ${ }^{21}$ and refined using a full matrix least square against $F^{2}$ for all data. All the non-H atoms were refined anisotropically. All hydrogen atoms were included in calculated positions with isotropic thermal parameters 1.2 times those of attached atoms. Crystallographic data are summarized in Table 1. Selected geometric parameters for the respective complexes are presented in Table 2 .

Supplementary Material. Supplementary crystallographic data associated to $\mathbf{L}$ has been deposited at the Cambridge Crystallographic Data Centre, CCDC No. 746974. Copies of the data can be obtained free of charge on application to CCDC, 12 Union road, Cambridge CB2 1EZ, UK (fax: +44 1223336 033; e-mail: deposit@ccdc.cam.ac.uk), or electronically via www. ccdc.cam.ac.uk/data_request/cif.

Acknowledgments. This work was supported by Kyungnam University Foundation Grant, 2008.

\section{References}

1. Grandjean, P.; Weihe, P.; White, R. F.; Debes, F. Environ. Res. 1998, $77,165$.

2. Takeuchi, T.; Morikawa, N.; Matsumoto, H.; Shiraishi, Y. Acta Neuropathol. 1962, 2, 40.

3. Harada, M. Crit. Rev. Toxicol. 1995, 25, 1.

4. Lee, S. J.; Lee, J.-E.; Seo, J.; Jeong, I. Y.; Lee, S. S.; Jung, J. H. Adv. Funct. Mater. 2007, 17, 3441.

5. Kim, S. H.; Sang, J. S.; Park, S. M.; Chang, S.-K. Org. Lett. 2006, 8,371 .

6. Sakamoto, H.; Ishikawa, J.; Nakao, S.; Wada, H. Chem. Commun. 2000, 2395.

7. Moon, S. Y.; Cha, M. R.; Kim, Y. H.; Chang, S.-K. J. Org. Chem. 2004, 69, 181.

8. Yang, Y. K.; Yook, K. J.; Tae, J. J. Am. Chem. Soc. 2005, 127, 16760.

9. Prodi, L.; Bargossi, C.; Montalti, M.; Zaccheroni, N.; Su, N.; Bradshaw, J. S.; Izatt, R. M.; Savage, P. B. J. Am. Chem. Soc. 2000, 122, 6769.

10. Shihadeh, Y. A.; Benito, A.; Lloris, J. M.; Martínez-Máñez, R.; Pardo, T.; Soto, J.; Marcos, M. D. J. Chem. Soc., Dalton Trans. 2000, 1199.

11. Ji, H.; Yoo, J. K.; Lee, H. S.; Park, K.-M.; Kang, Y. J. Bull. Korean Chem. Soc. 2010, 31, 1371.

12. Lee, H. G.; Lee, J.-E.; Choi, K. S. Inorg. Chem. Commun. 2006, 9, 582.

13. Yuan, M.; Li, Y.; Li, C.; Liu, X.; Lv, J.; Xu, J.; Liu, H.; Wang, S.; Zhu, D. Org. Lett. 2007, 9, 2313.

14. Martínez, R.; Espinosa, A.; Tárraga, A.; Molina, P. Org. Lett. 2005, 7, 5869 .

15. Jiménez, D.; Martínez-Máñez, R.; Sancenón, F.; Ros-Lis, J. V.; Soto, J.; Benito, Á.; García-Breijo, E. Eur. J. Inorg. Chem. 2005, 2393.

16. Boiocchi, M.; Fabbrizzi, L.; Licchelli, M.; Dacchi, D.; Vázquez, M.; Zampa, C. Chem. Commun. 2003, 1812.

17. Fabbrizzi, L.; Liccheli, M.; Poggi, A.; Sacchi, D.; Zampa, C. Polyhedron 2004, 23, 373.

18. Bag, B.; Bharadwaj, P. Inorg. Chem. 2004, 43, 4626.

19. Callan, J. F.; Prasanna de Silva, A.; Ferguson, J.; Huxley, A. J. M.; O'Brien, A. M. Tetrahedron 2004, 60, 11125.

20. Bruker, SMART and SAINT: Area Detector Control and Integration Software Ver. 5.0; Bruker Analytical X-ray Instruments: Madison, Wisconsin, 1998.

21. Bruker, SHELXTL: Structure Determination Programs Ver. 5.16; Bruker Analytical X-ray Instruments: Madison, Wisconsin, 1998.

22. Jin, Y.; Yoon, I.; Seo, J.; Lee, J.-E.; Moon, S. T.; Kim, J.; Han, S. W.; Park, K.-M.; Lindoy, L. F.; Lee, S. S. Dalton Trans. 2005, 788.

23. Lee, S. J.; Jung, J. H.; Seo, J.; Yoon, I.; Park, K.-M.; Lindoy, L. F.; Lee, S. S. Org. Lett. 2006, 8, 1641. 